\title{
CAMBridge
}

\section{English Language Teaching}

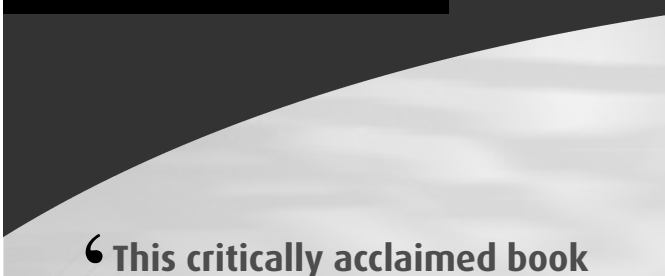

deserves to be widely read and debated by both English teaching professionals and language policy experts. $?$

TEFL.net

6 Highly recommended for faculty TOEFL training, this book will be invaluable for supporting learners from multiple nationalities.?

IATEFL Voices

6 ... an extensive, richly illustrated survey of Englishes from around the world.? English World-Wide

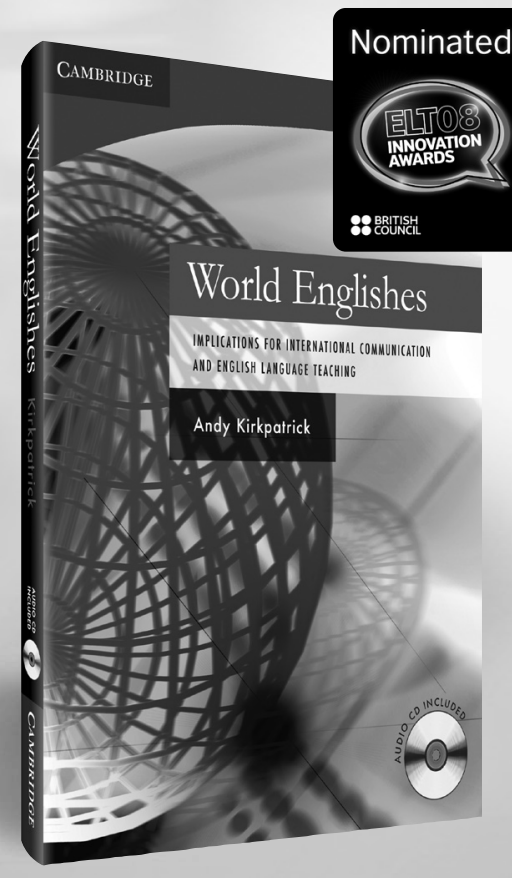

$\square$ discusses the implications of World Englishes on English language learning and teaching

$\square$ explores the roles and contributions of multilingual and multicultural English language teachers

$\square$ includes an audio CD of authentic examples of World Englishes

www.cambridge.org/elt/worldenglishes 


\section{CAMBRIDGE}

\section{Leaders in Language and Linguistics from Cambridge}

Language, Usage and

Cognition

JoAn Bybee

\$99.00: Hb: 978-0-521-85140-4: $262 \mathrm{pp}$ \$39.99: Pb: 978-0-521-61683-6

The Cambridge

Encyclopedia

of Language

\section{$3 \mathrm{rd}$}

Edition

DAVID CRYSTAL

\$99.00: Hb: 978-0-521-51698-3: $512 \mathrm{pp}$ \$45.00: Pb: 978-0-521-73650-3

Early Modern English Dialogues Spoken Interaction as Writing

JonAtHAN CULPEPER

MerJa KYtö

Studies in English Language

\$110.00: Hb: 978-0-521-83541-1: 494 pp.

\section{Colonial Voices}

A Cultural History of English in Australia, 1840-1940

JoY Damousı

Cambridge Social and Cultural Histories \$95.00: Hb: 978-0-521-51631-0: 300 pp.

The Evolution of Language

W. Tecumseh Fitch

\$120.00: Hb: 978-0-521-85993-6: 624 pp. \$55.00: Pb: 978-0-521-67736-3

Adjunct Adverbials in English

HILDE HASSELGÅRD

Studies in English Language

\$105.00: Hb: 978-0-521-51556-6: 338 pp.
The Evolution of

Human Language

Biolinguistic Perspectives

EDITED BY

RICHARD K. LARSON

Viviane Déprez

HIROKO YAMAKIDO

Approaches to the

Evolution of Language

\$105.00: Hb: 978-0-521-51645-7: $280 \mathrm{pp}$. \$41.00: Pb: 978-0-521-73625-1

Latin Alive

The Survival of Latin in English and Romance Languages

JOSEPH B. SOLOdOW

\$88.99: Hb: 978-0-521-51575-7: 364 pp. \$22.99: Pb: 978-0-521-73418-9

Why Do Languages

Change?

LARRY TRASK

\$88.99: Hb: 978-0-521-83802-3: 210 pp. \$27.99: Pb: 978-0-521-54693-5

Pragmatics and Non-Verbal Communication

TIM WHARTON

\$99.00: Hb: 978-0-521-87097-9: 230 pp. \$34.99: Pb: 978-0-521-69144-4

The Study of Language

GEORGE YULE

\$85.00: Hb: 978-0-521-76527-5: 338 pp. \$29.99: Pb: 978-0-521-74922-0
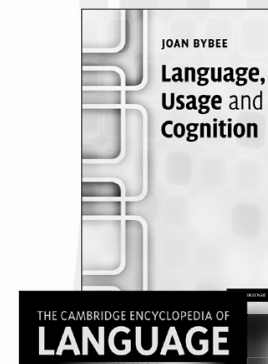

DAVID CRYSTAL

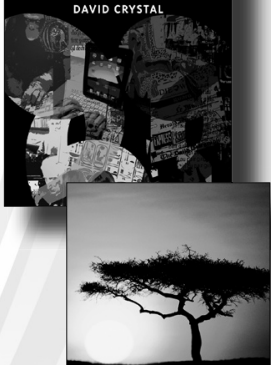

The Evolution of Language

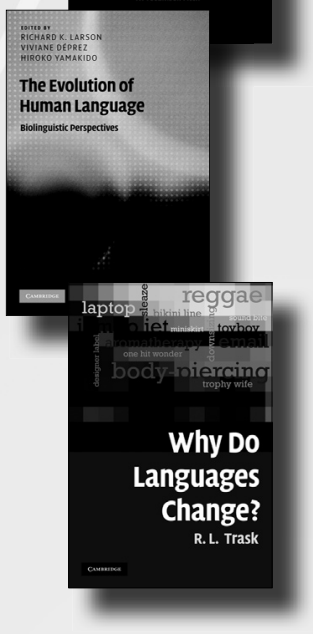

Price subject to chang www.cambridge.org/us

800.872 .7423
圈圈 CAMBRIDGE UNIVERSITY PRESS 


\section{INSTRUCTIONS FOR CONTRIBUTORS}

Submitted papers as well as general correspondence should be sent to the appropriate editor, as follows:

Bas Aarts: papers on present-day English syntax and morphology, papers not obviously falling under any of the areas listed below, and all reviews

David Denison: papers on historical syntax and morphology

April McMahon: papers on historical and present-day phonetics and phonology

Professor Bas Aarts

Editor, English Language and Linguistics

c/o Department of English Language and Literature

University College London

Gower Street, London WC1E 6BT, UK

E-mail: b.aarts@ucl.ac.uk

\section{Professor David Denison \\ E-mail: david.denison@manchester.ac.uk}

Professor April McMahon

E-mail: April.McMahon@ed.ac.uk

North American contributors may, if they prefer, submit manuscripts to:

Professor Douglas Biber

Associate Editor, English Language and Linguistics

Department of English

Northern Arizona University

Flagstaff, AZ 86011-6032, USA

E-mail: douglas.biber@nau.edu

Submission of an article is taken to imply that it has not been previously published or is not being considered for publication elsewhere.

\section{Manuscripts}

1. Manuscripts should not exceed 10,000 words (or equivalent). Shorter pieces and squibs are welcome.

2. Authors should submit to the appropriate editor an electronic copy of the paper, preferably in Microsoft Word DOC format. The name(s) of the author(s) and full contact details should be on a separate page at the start of the document. Occasionally, an author may be asked to send a paper copy of the manuscript by post or a PDF version as well.

3. If an accepted manuscript departs significantly from the style specified below, the contributor may be asked to reformat it. Detailed instructions for contributors are available at http://assets.cambridge.org/ELL/ELL_ifc.pdf.

4. Authors of accepted articles will be asked to assign copyright, on certain conditions, to Cambridge University Press.

\section{Style}

1. Manuscripts accepted for publication must be doubled-spaced throughout. The first lines of paragraphs, except when the first paragraph of a new section or sub-section, should be indented. There should be no extra space between paragraphs. Italics may be used in the manuscript.

2. Section headings should be typed on a separate line in capitals. Capitalise only first word and proper names in subsection headings.

3. All pages should be consecutively numbered in the top right-hand corner. The various elements of the manuscript should be ordered as follows: title, abstract (maximum 150 words), text, notes (to be typeset as footnotes) and figures. In the final manuscript the name(s) and correspondence address of the author(s) should be typed at the end of the text.

4. Authors should consistently follow either British English or US conventions for spelling and expression. In words with alternative -ize/ise use -ize, but note that analyze is acceptable only in US spelling.

5. Displayed examples should be numbered as follows, and referred to elsewhere as (1), (2a), etc:

(1) John liked Mary.

(2) (a) John always liked Mary.

(b) John never liked Mary.

Tree diagrams should be numbered in with examples. Other figures and tables should be numbered figure 1, table 1, etc., and each should have a caption. Each figure (other than tree diagrams) should be on a separate page, with an indication of its approximate position in the text.

6. Footnotes, which must also be double-spaced, should be numbered consecutively starting from 1. Footnote indicators in the text should be outside punctuation.

7. References in the text follow the normal author-date style: (Vincent 1997: 90-1); Vincent (1997) states ... For multiauthored works, only the first citation should list all authors: (Brown, Smith \& Jones 1996). In subsequent citations, only the first name should be given followed by et al. Separate works referred to in the same parentheses should be listed in alphabetical order: (Brown 1996; Smith 1991, 1992).

8. An alphabetical listed headed REFERENCES should start on a fresh page, double-spaced throughout. There should be no extra space between entries; the second and subsequent lines of each entry should be indented. Where more than one work by the same author is listed, the author's name should be repeated in each entry. The ampersand, \&, should be used with joint authors.

9. The following conventions should be observed:

\section{Book}

Surname, First name \& First name Surname. 1997. Title with capital letters only for first word and Proper Nouns. Place: Publisher.

Article in book

Surname, First name. 1997. Article title with capital letters only for first word and Proper Nouns. In First name Surname, \& First name Surname (eds.), Book title as above, 345-56. Place: Publisher.

\section{Article in journal}

Surname, First name. 1997. Article title as above. Journal Name with Content Words in Capital Letters 24, 121-9.

10. Proofs will be sent to the (first-named) author as PDF files. They should be returned within 3 days of receipt.

11. 25 offprints of articles and review articles will be provided free of charge to the (first-named) author. Additional offprints may be purchased if ordered at proof stage on the form provided. Authors of reviews will receive one copy of the issue in which their review appears.

This journal issue has been printed on FSC-certified paper and cover board. FSC is an independent, non-governmental, notfor-profit organization established to promote the responsible management of the world's forests. Please see www.fsc.org for information. 


\section{ENGLISH LANGUAGE LINGUIST I CS}

VOLUME 14 PART 2 JULY 2010

SPECIAL ISSUE

Future time reference in English

Edited by Ilse Depraetere and Christopher Williams

161 Introduction by the guest editors

ARTICLES 163 The development of future time expressions in Late Modern English: redistribution of forms or change in discourse?

Nadja Nesselhauf

187 Will: tense or modal or both?

Raphael Salkie

217 Expressions of futurity in contemporary English: a Construction Grammar perspective

Alexander Bergs

239 Beyond aspect: will be -ing and shall be -ing Agnès Celle and Nicholas Smith

271 Future time reference expressed by be to in Present-day English Renaat Declerck 